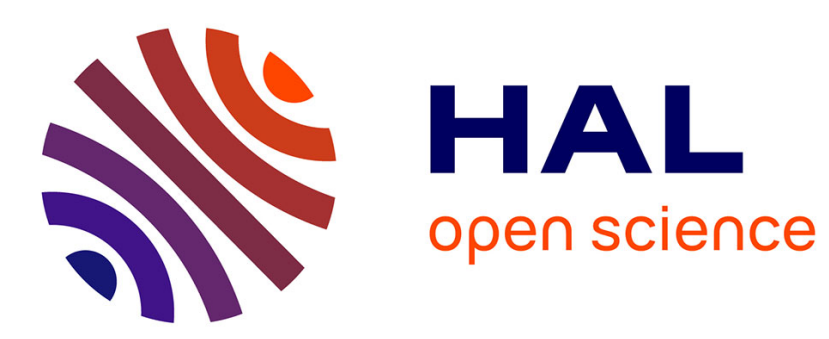

\title{
THE EFFECT OF CORPORATE GOVERNANCE ON STOCK REPURCHASES: EVIDENCE FROM SWEDEN
}

\author{
Andreas Jansson, Ulf Larsson-Olaison
}

\section{- To cite this version: \\ Andreas Jansson, Ulf Larsson-Olaison. THE EFFECT OF CORPORATE GOVERNANCE ON STOCK REPURCHASES: EVIDENCE FROM SWEDEN. Corporate Governance: An International Review, 2010, 18 (5), pp.457. 10.1111/j.1467-8683.2010.00803.x . hal-00613804}

\section{HAL Id: hal-00613804 \\ https://hal.science/hal-00613804}

Submitted on 6 Aug 2011

HAL is a multi-disciplinary open access archive for the deposit and dissemination of scientific research documents, whether they are published or not. The documents may come from teaching and research institutions in France or abroad, or from public or private research centers.
L'archive ouverte pluridisciplinaire $\mathbf{H A L}$, est destinée au dépôt et à la diffusion de documents scientifiques de niveau recherche, publiés ou non, émanant des établissements d'enseignement et de recherche français ou étrangers, des laboratoires publics ou privés. 


\section{Corporate Governance An International Review}

\section{THE EFFECT OF CORPORATE GOVERNANCE ON STOCK REPURCHASES: EVIDENCE FROM SWEDEN}

\begin{tabular}{|r|l|}
\hline Journal: & Corporate Governance: An International Review \\
\hline Manuscript ID: & CGIR-2009-0248.R2 \\
\hline Manuscript Type: & Original Manuscript \\
\hline Keywords: & $\begin{array}{l}\text { Internal CG: Ownership Issues, Dividend Policy < Board Policy } \\
\text { issues, Scandinavia < Governance Environments, Board Policy } \\
\text { issues }\end{array}$ \\
\hline
\end{tabular}

\section{ScholaroNE \\ Manuscript Central}




\title{
THE EFFECT OF CORPORATE GOVERNANCE ON STOCK REPURCHASES:
} EVIDENCE FROM SWEDEN

\begin{abstract}
Manuscript type: Empirical

Research Question/Issue: The paper examines whether corporate governance differences affect firms' stock repurchasing behaviour. Previous hypotheses on stock repurchases, wellsupported by US data, are based on assumptions of managerial autonomy that might not be descriptive in corporate governance systems characterised by influential controlling shareholders such as the Swedish. Firm-level corporate governance arrangements may also affect firms' incentives to repurchase stock.

Research Findings/Insights: Stock-repurchasing patterns among Swedish firms differ from those previously observed among US firms. The findings indicate that Swedish firms do not repurchase stock to distribute excess cash, signal undervaluation or fend off takeovers. Stock repurchases are made in addition to dividends and thus do not substitute for them. Firm-level corporate governance arrangements directly affect stock repurchasing behaviour. Firms without a dominant controlling owner seem to use stock repurchases to increase leverage. The existence of a dominant controlling shareholder diminishes the propensity for stock repurchases, while cross listing on a US or UK stock market increases that propensity. Theoretical/Academic Implications: The findings suggest that corporate governance differences affect stock repurchasing behaviour. The agency-theoretical view of the firm, on which the leading hypotheses on stock repurchases are based, accurately predicts stock repurchases only in certain institutional and governance settings.

Practitioner/Policy Implications: The study suggests that differences in national and firmlevel corporate governance must be taken into account in order to accurately assess outcomes of regulatory reforms and/or harmonisation attempts.
\end{abstract}

\section{KEYWORDS}

Corporate Governance; Stock Repurchases; Sweden; Dividends. 


\section{INTRODUCTION}

This paper examines the issue of whether corporate governance differences affect firms' stock repurchasing behaviour. The paper tests whether five well-established hypotheses can explain stock repurchases among Swedish firms. These hypotheses are grounded in agency-theoretical reasoning and have often been found to explain stock repurchases in the US context. The issue at stake here is whether they can be generalised to a context with substantially different corporate governance arrangements: the Swedish. The paper also explores the impact of a set of firm-level corporate governance variables on stock repurchases. The results suggest that the hypotheses grounded in agency theory are unfit for explaining stock repurchases among Swedish firms, which is likely to be an effect of differences in corporate governance arrangements between Swedish and US firms. The paper identifies controlling shareholder salience and heightened exposure to Anglo-Saxon capital markets as important factors shaping stock-repurchasing behaviour among Swedish firms.

Previous research has hypothesised that stock repurchases constitute a way of distributing temporary excess cash (Fenn \& Liang, 2001; Guay \& Harford 2000; Jagannathan, Stephens, \& Weisbach, 2000). It has also been suggested that stock repurchases are a substitute for dividends (Dittmar, 2000; Grullon \& Michaely, 2002; Skinner, 2008). Moreover, various forms of the signalling hypothesis suggest that the motivation behind stock repurchases may be that management wishes to signal perceived unfair low valuation of the firm's stock (Chang \& Sullivan, 2007; Dittmar, 2000; Ikenberry, Lakonishok, \& Vermaelen, 1995; Jun, Jung, \& Walkling, 2009; Lakonishok \& Vermaelen, 1990; Louis \& White, 2007; Sanders \& Carpenter, 2003; Vermaelen, 1981). Furthermore, it has been hypothesised that the underlying motive behind stock repurchases may sometimes lie in an attempt by management to fend off take-overs (Billett \& Xue, 2007; Chang \& Sullivan, 2007; Denis, 1990; Dittmar, 2000; Vermaelen, 1984). Yet another hypothesis on the motives behind stock repurchases is 
that firms may repurchase stock to increase leverage (by decreasing outstanding equity) towards an optimal level that minimises agency and financing costs (Dittmar, 2000; Opher \& Thakor, 1987; Wansley, Lane, \& Sarkar, 1989).

These hypotheses are not necessarily mutually exclusive, and have all gained substantial empirical support when tested with US data. They have, however, been developed to explain the behaviour of US firms, operating in a corporate governance system characterised by a comparatively high degree of ownership dispersion, managerial autonomy, and fraction of compensation that is performance-based (Gedajlovic \& Shapiro, 1998; Weimer \& Pape, 1999). These assumptions of managerial autonomy and motivations can be associated more generally with an agency-theoretical view of the firm. This view has received criticism for being US-centric, failing to take into account the effects that embeddedness of corporations in varying institutional contexts have on corporate actions (Aguilera \& Jackson, 2003; Fligstein \& Freeland, 1995; Gospel \& Pendleton, 2005; Lubatkin, Lane, Collin, \& Very, 2005; O'Sullivan, 2002). The pertinent agency problem in a corporate governance system, for example, is likely to vary with the relative strength of internal and external governance mechanisms (Dharwadkar, George, \& Brandes, 2000).

Swedish corporate governance, like most corporate governance systems throughout the world (La Porta, Lopez-De-Silanes, \& Shleifer, 1999), is characterised by powerful controlling shareholders who are actively involved in firms' governance (Agnblad, Berglöf, Högfeldt, \& Svencar, 2001; Stafsudd, 2009). Swedish controlling shareholders are, for example, typically involved in board work (Dzialo, Jonnergård, Kärreman, Svensson, \& Urbanek, 1998; Jonergård \& Kärreman, 2004; Jonnergård \& Larsson, 2007). Moreover, managerial compensation in Sweden is, compared to US conditions, to a lesser degree performance-based (Oxelheim, Wihlborg, \& Zhang, 2008; Weimer \& Pape, 1999). All this suggests that Swedish firms in general are characterised by substantially greater influence of 
powerful and active owners on board-level decisions such as stock repurchases, and less capital-market pressures on top managers, than US firms, although there may of course be firm-level variation on these dimensions in the Swedish context. To the extent that large owners and managers less incentivised by financial performance face different incentives from the more autonomous US managers regarding stock repurchases, these institutional differences may cause hypotheses on stock repurchases developed with US firms in mind to hold less explanatory power in the Swedish context.

This paper tests whether the hypotheses derived from an agency-theoretical view of the firm, which have received previous empirical support when tested on US data, can explain stock repurchases among Swedish firms, to explore whether the institutional differences in corporate governance between these two countries may produce dissimilar patterns of stock repurchases. We furthermore test whether variation in firm-level corporate governance arrangements affects stock repurchases, to explore whether Swedish firms governed more or less similarly to US firms exhibit dissimilar repurchasing patterns. Understanding how variation in corporate governance affect stock repurchases will arguably constitute one contribution towards a better understanding how institutional embeddedness of corporations impacts the behaviour of these corporations.

We find evidence that partially supports the leverage hypothesis, but not the other hypotheses. A sub-sample analysis reveals that the leverage hypothesis predicts stock repurchases for firms without a large shareholder ( $>25 \%$ of the votes), but not for other firms. Dividends are, contrary to expectations, positively related to stock repurchases, suggesting that stock repurchases are generally made in addition to dividends rather than as a substitute for them. Firms cross-listed in the US or UK are more prone to stock repurchases, whereas the presence of a large shareholder is negatively related to stock repurchases. Overall, this indicates that since board-level decisions such stock repurchases are likely to be under the 
control of large shareholders, and large shareholders are likely to have interests that are different from those of an autonomous management, hypotheses formulated within the agency-theoretical framework are generally unfit for explaining stock repurchases among Swedish firms.

The next section describes the historical development and characteristics of Swedish corporate governance. The section that follows reviews the literature on stock repurchases and develops the hypotheses to be tested, followed by a section detailing the sample and variables used. The paper continues by presenting the test results, followed by a discussion and conclusion.

\section{THE SWEDISH CORPORATE GOVERNANCE SYSTEM}

As described by Agnblad et al. (2001), corporate governance in Sweden is characterised by highly concentrated ownership of listed firms. In fact, Swedish listed firms exhibit among the highest ownership concentrations in the world when measured as concentration of votes, which is facilitated by legal provisions that can be used simultaneously, such as dual-class shares and pyramid and cross ownership. These allow concentration of votes without corresponding ownership of cash flow rights. Sweden is also often argued to have only moderate formal minority protection in international comparisons (La Porta et al., 1999; Nenova, 2003), leading to a situation in which minority expropriation and a small and inactive stock market might be expected. Yet Sweden has liquid financial markets (Agnblad et al., 2001; Stafsudd, 2009) and very little minority shareholder expropriation from an international perspective (Gilson, 2006; Nenova, 2003).

These rather paradoxical facts are often said to be the effect of controlling owners that monitor management while refraining from exploiting minority shareholders for reasons of social prestige and reputational considerations (Agnblad et al., 2001; Jansson, 2007; Stafsudd, 2009). The large controlling shareholders are typically represented on the 
board of directors, where they are considered hierarchically superior by other board members (Kärreman, 1999), and can control the annual general meetings and thus hire and fire management at will (Collin, 1998; Jonnergård \& Kärreman, 2004). At the same time, Swedish controlling owners are themselves monitored. The Swedish corporate governance system exhibits tightly knit personal networks among owners of firms (Sinani, Stafsudd, Thomsen, Edling, \& Randøy, 2008; Stafsudd, 2009). This creates a situation in which owners operate in small worlds where information travels quickly and reputations for honesty are likely to become valuable, thus creating an environment in which minority expropriation is curbed (Stafsudd, 2009).

Assuming that the Swedish corporate governance situation is path-dependent (Bebchuck \& Roe, 1999), clues to these features of the Swedish corporate governance system could be found in its history. According to Högfeldt (2005) the Swedish corporate governance situation should be viewed in light of historical compromises reached by the large business owners, the trade unions and the Social Democratic Party. When the Social Democrats came into power in the 1930s, Swedish economic policy was geared towards supporting very large firms in which discernible capitalists, available for negotiations, were in control. As Aguilera and Jackson (2003) predicts, the result was firms in the hands of the highly committed large owners, partly pursuing strategic goals such as prestige and social esteem (Agnblad et al., 2001; Stafsudd, 2009). This also facilitated a corporatist model of negotiations and compromises, in which private ownership by large owners was respected as long as they participated in achieving full employment and social reforms (Högfeldt, 2005).

As a consequence of the corporatist model employed, a number of very powerful business groups, often centred on families, could control multiple firms on the Stockholm Stock Exchange (SSE) (Collin, 1998). However, the concentration of power by controlling owners is also a general feature in firms independent from these business groups, 
which could also take advantage of the legal provisions used by large business groups to concentrate voting power. Moreover, economic success for Swedish firms is often said to be the effect of directing the business society's resources to a few export-oriented industries, often with government support (e.g., Glete, 1994; Högfeldt, 2005). This resulted in a highly internationalised business society.

However, just as the present situation in Swedish corporate governance system is rooted in the past, recent changes have certainly sprung from globalisation; at least from a perceived pressure for change due to globalisation among business leaders and the government. The 1980s saw the start of massive deregulation of what had been a highly regulated capital market, making the Swedish markets de jure more akin to US and UK markets. This resulted, among other things, in a massive influx of foreign ownership to go with what were already very internationalised firms; foreign ownership on the SSE is now about $30-35 \%$ (Statistics Sweden). Another reform that emerged from this was that stock repurchases were allowed in 2000; this met hardly any resistance from the business community, suggesting that the reform was perceived as beneficial, or at least not harmful. After this reform the Swedish Companies Act stipulated that a decision to repurchase stock or to pay a dividend is a decision to be taken by the shareholders at a general assembly, which in practice almost invariably mandates the board of directors to take this decision. ${ }^{1}$

Firms also changed in response to globalisation. For example, the use of option schemes to reward top managers in Swedish firms became popular in the late 1990s. However, variable pay, though by now common, still constitutes a much smaller part of total remuneration for Swedish managers than for managers in most other countries. Around a third of a Swedish CEO's remuneration comes from variable pay systems (Oxelheim et al., 2008); the comparable number for US managers is over $80 \%$ (Murphy, 1999). This may be an effect of more active owner monitoring, making performance-based pay less necessary for aligning 
managers' and owners' incentives (cf. Eisenhardt, 1989). Despite globalisation, the Swedish model of powerful controlling shareholders still prevails and has proved itself very flexible throughout the course of history, adapting to, for example, the internationalisation of corporate ownership and the regulations that followed this development (Jonnergård \& Larsson, 2010).

We thus have good reason to suspect that, in general, controlling owners constrained by a willingness to uphold a reputation for honesty, play a dominant role in board-level decision making in Swedish firms, such as in the decision to repurchase stock. The use of owner monitoring rather than performance-based pay to align managerial incentives with that of the (large) owners may also create a situation in which managers are shielded from capital market pressures to a higher extent than, for example, managers in the United States or the UK. Finally, although there may be a typical Swedish model of corporate governance, many Swedish firms are highly internationalised, both in terms of ownership (in some cases due to cross listings) and product market orientation, although foreign owners as minority shareholders will tend to have little direct influence compared to the dominant controlling shareholders (cf. Agnblad et al., 2001).

\section{LITERATURE REVIEW AND HYPOTHESES DEVELOPMENT}

In recent times, the dominant theoretical perspective in the analysis of corporate governance issues has been agency theory (Turnbull, 1997), a theory that has been accused of 'made-in-the-US' bias and of a failure to account for how embeddedness of corporations in varying institutional contexts affects, for instance, corporate organisation and decision making (Aguilera \& Jackson, 2003; Fligstein \& Freeland, 1995; Gospel \& Pendleton, 2005; Lubatkin et al., 2005; O'Sullivan, 2002). Specifically, agency theoretical understandings of corporate governance issues typically presume absent owners and autonomous managers whose utility is highly dependent on stock performance (Aguilera \& Jackson, 2003), which are features that 
may not necessary be descriptive of the Swedish corporate governance system, or many other corporate governance systems around the world. Agency theory and the accompanying assumptions of autonomous managers who are sensitive to capital market pressures can also be seen as the overarching framework for the dominant hypotheses on stock repurchases.

In this study we explore the impact of differences in corporate governance on stock repurchases. This is done, first, by empirically testing the extent to which leading hypotheses on stock repurchases, which have received widespread support when tested on US data, can explain stock repurchases among Swedish firms. Second, we do this by testing whether firm-level corporate governance arrangements that cause firms to be governed more or less as their US counterparts, impact firms' stock-repurchasing behaviour. In this section, we outline the five leading hypotheses on stock repurchases under test, and consider how the characteristics of Swedish corporate governance might impact their applicability to stock repurchases among Swedish firms, and then formulate a sixth hypothesis suggesting how firm-level corporate governance arrangements may affect stock repurchases. We begin, however, by outlining the basic agency-theoretical understanding of stock repurchases that frame the leading hypotheses.

\section{Stock repurchases in agency theory}

In agency theory, the firm is a nexus of contracts among various principals and agents (Alchian \& Demsetz, 1972; Fama, 1980; Jensen \& Meckling, 1976). As stated in the seminal work of Jensen and Meckling (1976), the agency theoretical model rests on a number of assumptions, for example, choices by economic agents are motivated by their self-interest and information asymmetry between management (agents) and shareholders (principals). It is typically presumed that management are separate from owners and that there is a conflict of interest between shareholders and managers (Fama, 1980; Fama \& Jensen, 1983; Jensen 1986) and between shareholders and debt holders (Jensen \& Meckling 1976). These conflicts 
of interest lead to agency costs (e.g. costs for monitoring, ex ante bonding and residual losses).

Stock repurchasing is a method of cash distribution from the firm to shareholders that, over the years, has grown in popularity in the United States, especially open market share repurchasing (e.g., Dittmar, 2000; Fenn \& Liang, 2001; Jagannathan et al., 2000). It is often seen as an alternative to cash dividends, but differs from it in some significant aspects. A share repurchase, in contrast to a cash dividend, is not an irrevocable distribution of cash from the firm to shareholders. If not annulled, the repurchased shares may be sold back to investors, or be used as payment in acquisitions. However, the shares, in accordance with the logic that a firm cannot own itself, have no real value when owned by the firm. Hence, share repurchases do have a real effect on the firm's capital structure by increasing leverage.

According to Jensen (1986), optimal capital structure occurs when the sum of the agency costs of equity and the agency costs of debt is minimised, and thus the market value of the firm is maximised. However, as pointed out by Stulz (1990), a management separate from owners is unwilling to achieve optimal capital structure. Management are likely to prefer a lower leverage, since this leaves them in control of more cash flow that can be used to pursue their own ends, untouched by contractually specified, scheduled interest payments and repayment of debt. Cash flow over and above what can be profitably invested is referred to as free cash flow (Jensen, 1986) and is thus an effect of lower than optimal leverage, which may lead to agency costs as management has incentives to invest the cash flow rather than distribute it to shareholders. Presuming an autonomous management that has incentives to achieve a lower leverage than optimal, a transaction that intentionally increases leverage (as a stock repurchase) should, according to agency theory, be interpreted by a 
rational investor as a transaction that will decrease future agency costs, as it implies less free cash flow under management's control (cf. Harris \& Raviv, 1991).

If an autonomous management were given total freedom to pursue its own interests, the firm's leverage would thus presumably be lower than optimal. Nevertheless, several control mechanisms constrain managerial discretion. As suggested by Walsh and Seward (1990), these constraints may be classified as external and internal. External constraints are market-based mechanisms such as the market for corporate control and hostile take-overs (Gedajlovic \& Shapiro, 1998; Jensen, 1986), the managerial labour market (Fama, 1980), and not least, pay made contingent on stock performance, which can exert considerable influence on managerial decision making (Lazonick, 2007). Internal constraints are organisationally based mechanisms, such as monitoring by the board of directors (Fama \& Jensen, 1983) or the internal market for promotions (Fama, 1980). It is often assumed that the US and UK corporate governance systems depend on external constraints, whereas continental European systems depend more on internal constraints (Gedajlovic \& Shapiro, 1998).

The Swedish corporate governance system relies mainly on internal control mechanisms for controlling management; in particular active owners who exert control through representation on boards of directors. The agency-theoretical understanding of stock repurchases presumes that management controls firms' decision to repurchase stock, but, as argued above, we doubt that this may be true in the Swedish context, where controlling shareholders are likely to exert considerable influence over this decision. Controlling shareholders, however, may, similar to management, have reasons to prefer a lower-thanoptimal leverage, since they typically have invested a large part of their portfolio in one firm and therefore may have an interest in decreasing the default risk of that firm. 


\section{Hypotheses on stock repurchases based on agency theory}

What motivates firms to repurchase stock? In this section, we will describe the five hypotheses that are tested in this study and link them to the agency-theoretical framework outlined above. These are a selection of what has been discussed in the literature and were appraised as the most persistent explanations of the rationale behind stock repurchases. We have, to some degree, synthesised ideas expressed by other researchers about stock repurchases in order to form the five hypotheses. The rationale for repurchasing stock typically presupposes an autonomous management whose wealth is highly linked to stock price performance. After stating each hypothesis, we consider how the specifics of Swedish corporate governance, especially the likely dominance of controlling owners over the decision to repurchase stock and managers less sensitised to capital market pressures, might affect their ability to predict stock repurchases among Swedish firms.

Management-controlled firms may be motivated to repurchase stock to alter their capital structure towards optimum, which according to agency theory is likely to increase the value of the firm. This assertion gained empirical support when tested with US data by, for example, Wansley et al. (1989) and Dittmar (2000), although the results of Chan, Ikenberry, and Lee (2004) seem to contradict this finding. For an autonomous manager subject to the discipline of the stock market, increasing the value of the firm is attractive, especially if the manager's remuneration is tied to the performance of the firm's stock. Moreover, according to agency theory, a higher value of the firm generally increases the management team's market value on the managerial labour market (Fama, 1980), and makes the firm less attractive as a take-over target (Jensen, 1986) or a target for shareholder activism (Strickland, Wiles, \& Zenner, 1996). Hence, the more a firm's leverage negatively differs from the optimal level (i.e. the more free cash flow the firm generates), the greater the volume 
H1: There is a negative relationship between firm leverage and extent of stock repurchases.

It is straightforward to see why a manager whose wealth is tied to the market value of the firm may want to repurchase stock to leverage the managed firm if this increases its value. If this hypothesis can predict stock repurchases in the Swedish context with managers less exposed to the discipline of the market and large shareholders likely to largely be in control of stock repurchasing decisions is, however, less obvious. On the one hand, a major shareholder, whose wealth often is largely synonymous with the value of the firm, may have an interest in increasing firm value. However, some differences between the situation faced by an autonomous manager and a large owner may be raised. Many controlling shareholders may be reluctant to sell the firm, making them care less about its immediate market value and more about default risk, while managers' rewards may depend more immediately on firm value (cf. Fama, 1980). Moreover, controlling shareholders are less likely to be disciplined by mechanisms such as hostile takeovers. To the extent that controlling shareholders influence Swedish firms' stock repurchases, leverage is thus likely to be a less important driver than for firms in contexts where ownership is more dispersed. Bohman's (2006) study of what affects the probability that a firm adopt a stock repurchasing program based on Swedish data consistently indicates that leverage has no effect.

While the leverage hypothesis focuses on recurring streams of free cash flow, liquid assets over and above profitable investment opportunities do not always have to come in a steady stream. It has been suggested, and empirically supported by, for example, Dittmar 
(2000), Fenn and Liang (2001), Guay and Harford (2000), and Jagannathan et al. (2000), that stock repurchases may be used to distribute temporary shocks of liquidity. Managementcontrolled firms may have an incentive to distribute cash over and above profitable investment opportunities to the shareholders to maximise firm value. If management decides to distribute temporary excess cash, it may prefer a stock repurchase as the method of distribution, in favour of a dividend. Jensen (1986) and Jagannathan et al. (2000) argue that stock repurchases are perceived as a weaker promise of future pay-outs; a decreased rate of dividends is typically punished by the capital market with large stock price reductions and may also be harmful to the reputation of managers (Gwilym, Morgan, \& Thomas, 2000). The more excess cash a firm possesses that cannot be invested in profitable investment opportunities, the greater the volume of stock repurchases that may be expected according to this rationale, ceteris paribus. Thus, the following hypothesis, referred to as the excess cash hypothesis, may be formulated:

\section{H2: There is a positive relationship between firm excess cash holdings and extent of stock repurchases.}

If board-level decisions, such as that of repurchasing stock, is controlled by large shareholders, as it is likely to typically be in the Swedish context, and if managers are to a less extent sensitised to stock market reactions, it is however less obvious why a stock repurchase would be preferred to a dividend. On the one hand, if the controlling shareholder has no intention to sell the firm, market reactions to temporary dividends may not play such a big role. On the other hand, using stock repurchases to distribute excess cash is a lower-risk transaction than an extraordinary dividend, as there is the possibility of selling the stock should the cash be needed after all. Moreover, if controlling shareholders, and Swedish 
managers alike, are less sensitive to negative market reactions to firms possessing excess cash, there may be weak incentives to distribute the cash in the first place. It is, thus, difficult to predict the extent to which contextual factors may affect the applicability of the excess cash hypothesis.

Stock repurchases may also be used as a substitute for dividends. This hypothesis has received empirical support in Grullon and Michaely (2002) and Skinner (2008), but is contradicted by Dittmar's (2000) and Jiraporn's (2006) results. Because of the weaker commitment to future payouts (Jagannathan et al., 2000; Jensen, 1986), a management-controlled firm may prefer a cash distribution policy, implying that a larger fraction of the corporate cash distribution is carried out by stock repurchases at the expense of dividends. Managers are more risk-averse than stockholders in widely held firms (Harris \& Raviv, 1991) and such a policy will allow for sudden cuts in corporate cash distribution without depressing the stock price, thus inducing less risk for a future depreciation of the management team's value on the managerial labour market (Fama, 1980) and slumps in performance-related pay. Grullon and Michaely (2002) also show that market reaction to decreasing dividends is not negative if the firm simultaneously engages in repurchasing stock. This suggests that when stock repurchases become an available alternative, a propensity for paying dividends might gradually decrease in favour of stock repurchases, ceteris paribus. Thus, the following hypothesis, referred to as the substitution hypothesis, may be formulated:

\section{H3: There is a negative relationship between firm dividends and extent of stock} repurchases.

Controlling shareholders may, like management, be more risk-averse than dispersed shareholders with diversified portfolios, but are also likely to be less driven my 
immediate market reactions. Therefore, they face less strong incentives to substitute stock repurchases for dividends, as the negative market reactions from lowering dividends as a response to poor performance is not as costly as for an autonomous manager. This suggests that the incentives for letting stock repurchases replace dividends in the Swedish context, in which controlling shareholders are likely to largely control the decision to repurchase stock, are weaker than in the US context.

These hypotheses are premised on the notion that managers have an incentive to ensure that the firm's market value increases, or at least does not decrease. Moreover, they assume that the firm is being valued fairly by the market. However, the point of departure for one of the most widely discussed explanations for stock repurchases is that the firm is not being valued fairly, or, more specifically, that managers of management-controlled firms perceive the firm to be undervalued. Management is assumed to have superior information than investors do about the firm. Asquith and Mullins (1986), Chang and Sullivan (2007), Dittmar, (2000), Ikenberry et al. (1995), Jun et al. (2009), Louis and White (2007), Netter and Mitchell (1989), Opher and Thakor, (1987), Sanders and Carpenters (2003) and Vermaelen (1981), among others, have argued that stock repurchases are under most circumstances interpreted by investors as a signal that management perceives the firm to be undervalued. In fact, firms need not even necessarily repurchase share for the signal to work, which has given rise to what is, among US firms, the common practice of announcing a stock repurchase program without necessarily repurchasing many shares. Stephens and Weisbach (1998) show, however, that given three years, firms tend to repurchase around $80 \%$ of what they promised. This hypothesis has been widely discussed and elaborated on and has also been empirically supported. Lakonishok and Vermaelen (1990), moreover, argue that the signalling effect increases with the volume of stock repurchased. Management-controlled firms are therefore likely to repurchase stock to signal perceived undervaluation of the firm if such exist. The 
H4: There is a negative relationship between firm valuation and extent of stock repurchases.

greater the perceived under-valuation, the greater the probability and volume of stock repurchases that may be expected according to this rationale, ceteris paribus. Thus, the following hypothesis, referred to as the signalling hypothesis, may be formulated:

It is easy to see why a manager whose rewards and career prospects are tied to the market value of the firm would want to signal that the firm is undervalued if that is the case. It is, however, less obvious why a controlling shareholder would extend resources for such signalling to fix a problem that in the longer run is likely to fix itself anyway. Unless a controlling shareholder plans to exit the firm, a more or less temporary undervaluation should be of less concern. Signalling under those circumstances could be interpreted more as a favour to the minority shareholders, which nonetheless may be a plausible outcome of pressures among Swedish controlling owners to improve their reputations (Stafsudd, 2009). Another caveat regarding signalling in the Swedish context is that the market may not necessarily understand what the signal means. Zajac and Westphal (2004) show that it took a long time for the US stock market to begin interpreting stock repurchases as a signal that the repurchasing firm is undervalued. Altogether, this suggests that the incentives to repurchase stock to signal undervaluation may be weaker in the Swedish than in the US context.

In the hypotheses outlined thus far, the market for corporate control, especially the threat of hostile take-overs, is a disciplining mechanism for managements in managementcontrolled firms. Management is motivated to keep the value of the firm high, so that it will not be an attractive target for take-over attempts. However, it has been suggested by, for instance, Chang and Sullivan (2007) Denis (1990), Dittmar (2000), Ikenberry et al. (1995) 
and Vermaelen (1984) that stock repurchases are used in order to fend off take-over attempts already in progress, or very closely imminent (Billett \& Xue, 2007) in some cases (i.e. as an instrument in ongoing corporate power struggles). A stock repurchase fills, at the very least, two desirable purposes for a management team whose jobs are potentially endangered by a take-over. (i) A stock repurchase is likely to increase firm value due to decreased future agency costs from increased leverage or signalling effects and thus decrease the potential gains from an acquisition. (ii) The owners who are willing to sell their shares at the lowest price will sell them to the firm; thus these shareholders will be removed (Bagwell, 1991). According to this rationale, the more obvious and severe the threat of a hostile take-over, the more likely a firm would be to repurchase stock, ceteris paribus. We may therefore formulate the following hypothesis, referred to as the control hypothesis:

\section{H5: There is a positive relationship between take-over threats and stock repurchases.}

Obviously, firms with a controlling owner who holds a large fraction of the shares are less attractive takeover targets unless large shareholders are willing to sell. For that reason, hostile takeovers have been very rare in Sweden (Agnblad et al., 2001), and accordingly we do not expect the control hypothesis to be as important for explaining stock repurchases in the Swedish as in the US context. However, for those few firms that have dispersed ownership, take-over threats can still induce stock repurchases, which is why we test this hypothesis empirically on a Swedish data set.

\section{The impact of firm-level corporate governance differences on stock repurchases}

We have considered how the general characteristics of the Swedish corporate governance system might limit the applicability of leading hypotheses on stock repurchases 
developed with US firms in mind. Overall, this discussion suggests that corporate governance factors may be important for firms' stock repurchasing behaviour. The literature can also give further clues as to what type of corporate governance factors may impact stock repurchases. Of particular interest is the literature focusing on stock repurchases outside an Anglo-Saxon context, which however is small, perhaps because stock repurchases have not been allowed for very long.

On a system-wide scale, the legal environment seems to matter. Gonzáles and Gonzáles (2004) show that a Spanish cap on the number of shares that companies can repurchase (similar caps exist in Sweden and other EU countries) induces firms to repurchase shares on the open market. In addition, the degree to which minority shareholders are protected may be of consequence. Jiraporn's (2006) study, conducted in the US, shows that stronger shareholder rights expressed in, for example, state law and corporate charters, assumed to force managers to act more in the interests of shareholders, prompt more repurchases of stock. Bohman (2006) uses survival analysis to show that the probability that a Swedish firm will engage in a stock repurchase program increases with board interlocks with other firms that repurchase stock, although the small worlds character of Swedish ownership and board networks (Sinani et al., 2008; Stafsudd, 2009) suggest that most boards are not many steps away from each other.

Ownership structure appears also to be linked to stock repurchases. Liljeblom and Pasternack (2006) show that foreign ownership increases stock repurchases among Finnish firms, and Ginglinger and l'Her (2006) show that the market reaction to announcements of stock repurchase programs vary with ownership structure in France, such that the market reacts more positively when the firm has large foreign ownership and when no single shareholder can dominate decision making and thus use repurchases for minority expropriation purposes. The latter is consistent with Jiraporn's (2006) findings on the positive 
link between shareholder protection and repurchases; however, Swedish firms, though certainly often dominated by controlling owners, exhibit very limited minority expropriation (Nenova, 2003; Stafsudd, 2009), so this effect may not be as strong in the Swedish context. Nevertheless, these studies indicate that beyond system-wide effects, ownership concentration and heightened exposure to the pressures of international investors might be linked to stock repurchases. International investors are predominantly situated in Anglo-Saxon contexts and might both expect and be more positive to stock repurchases (cf. Zajac \& Westphal, 2004) than other investors.

With the specifics and historical development of the Swedish corporate governance system in mind, this suggests that firms governed in more traditional Swedish ways (i.e. firms that are characterised by controlling shareholder dominance and limited influence of foreign investors), may be less induced to repurchase stock, ceteris paribus. This also appears consistent with our discussion about the applicability of hypotheses derived from agency theory in a context of controlling owner dominance. We may therefore formulate the following hypothesis, referred to as the governance hypothesis:

H6: There is a negative relationship between traditional Swedish corporate governance arrangements and stock repurchases.

\section{SAMPLE AND VARIABLES}

Swedish firms were allowed to repurchases stock for the first time in 2000. The sample consists of yearly observations of all firms listed on the SSE 2000-2004 on which full information could be obtained. This includes all Swedish firms that were allowed to repurchase stock, with the exception of a few smaller ones listed on alternative market places. The sample excludes firms quoted on SSE that were not incorporated in Sweden, as they 
operate in different legal regimes regarding stock repurchases. In total, the sample consists of 1304 observations of which 233 were from 2000, 263 from 2001, 279 from 2002, 275 from 2003, and 259 from 2004.

The dependent variable, 'Stock repurchases', is defined as actually incurred stock repurchases in terms of millions of Swedish crowns (MSEK) over a year. The independent variables of the study are summarised in Table 1.

Insert table 1 here

Firms' degree of leverage is captured by the variable 'Leverage', which is, similar to Sanders and Carpenter (2003) and others, defined as firms' debt-to-equity ratio. Consistent with, e.g., Dittmar (2000) two measures are used to capture excess cash, one capturing the stock and the other the flow of overliquidity: 'Current assets-to-total assets' and 'Cash flow-to-total assets', measured as the ratios of current assets and yearly cash flow to total assets, respectively. For banks and closed-end investment funds that do not account for current assets, total cash possessions were used instead.

The valuation of firms is captured by two variables: 'Market-to-book' and 'Earnings-to-price'. Market-to-book is defined as firms' market-to-book ratio, an established measure of potential undervaluation of firms (e.g., Bohman, 2006; Dittmar, 2000), and Earnings-to-price is measured as the ratio of earnings before tax to stock market capitalisation. The more traditional $\mathrm{P} / \mathrm{E}$ ratio could not be used as many firms had negative earnings during the period. Dividends are, as in Sanders and Carpenter (2003), measured as cash dividend payouts in terms of MSEK, captured by the variable 'Dividends'. Rumours of potential takeovers of firms are measured by a dummy variable, 'Rumour', that equals 1 if 
rumours of a potential takeover of the firm existed in the business press during year; if not it equals 0, similar to Dittmar (2000).

As in Dittmar (2000), all measures of independent variables are from the financial year preceding the year of stock repurchases (the end of this year for balance sheet and market value measures). This approach was chosen because of the hypothesised causal relationship that the nature of these fundamentals precede a stock repurchase. Moreover, in Sweden a stock-repurchasing scheme has to be authorised by the general assembly where the main source of information for the shareholders is the annual financial statement. Two exceptions exist, however: Dividends and Rumour. Dividends are measured at the year of stock repurchases to see whether stock repurchases substituted dividends. Dividends, too, have to be authorised by the general assembly. When measuring Rumours, take-over rumours for both the year of stock repurchases and the preceding year were recorded, as both imminent and ongoing take-over attempts may motivate stock repurchases (Billett \& Xue, 2007; Chang \& Sullivan, 2007).

We use three variables to capture the in-sample variation of firms' corporate governance arrangements, indicating whether firms are governed in ways more representative of traditional Swedish corporate governance or in ways more similar to US firms. One of the most prominent features of Swedish listed firms, as opposed to US ones, is the prevalence of major block holders that actively control corporations, often by means of dual-class shares (Agnblad et al., 2001). We therefore include dummy variables indicating whether a firm has dual-class shares and whether any one owner holds more than $25 \%$ of the votes at the beginning of the year. ${ }^{2}$ Firms with these characteristics may be regarded as more representative of traditional Swedish corporate governance, whereas other firms thus have governance characteristics more similar to US firms, even though they still exhibit high ownership concentration from a US perspective (cf. La Porta et al., 1999). We also include a 
dummy variable, 'Crosslisting', which indicates whether a firm is listed on the London Stock Exchange (LSE), NASDAQ and/or the New York Stock Exchange (NYSE); this variable proxy for heightened exposure to the pressures of international investors, which traditionally has been low for most Swedish firms.

We furthermore control for size, industry and year. The natural logarithm of total assets measured in MSEK, 'Log total assets', and dummy variables indicating year and which industrial sector firms belong to according to GICS, the classificatory standard used by SSE, are used for this purpose.

All accounting data were collected from the EcoWin and Datastream databases or directly from the firms' annual reports. Data on ownership structure, the presence of dualclass shares and market values were collected from the annual 'Owners and power' series, comprising highly reliable data on the ownership structures of listed Swedish firms. Data on stock repurchases and cross listing were collected from SSE's records. Data on take-over rumours were collected from Affärsdata's database that contains an archive of articles from the most important Swedish business press. A query with the search string containing the Swedish equivalent of 'take-over' was performed, and those firms mentioned as potential take-over targets were coded 1 and all others were coded 0 . The data collected on takeover rumours are, in contrast to all other data, obviously not as reliable. In order to test for this, we attempted to recode rumours of the year 2001, and the results differed very little from our first attempt, indicating that the reliability problem is not particularly serious. All multivariate tests have also been performed with the variable excluded, and the results presented in the remainder of this paper are robust to the inclusion of the Rumour.

\section{RESULTS}

Table 2 present descriptive statistics, VIF values and bivariate correlations (Pearson) among the variables and Table 3 compares the means for firms that did or did not 
repurchase stock, respectively (industry and year dummies are not reported). Table 3 also reports results from independent samples t-tests (t statistic) and Wilcoxon/Mann-Whitney Utests ( $\mathrm{z}$ statistic) to test for equality between the two groups.

Insert Table 2 here

Insert Table 3 here

The average firm of our sample repurchased stock worth MSEK 66.07, although the standard deviation is very large. The average dividend of MSEK 218.20, also with a high standard deviation, is about triple the size of the average stock repurchase. Considering that our sample encompasses the first five years in which stock repurchases were allowed for Swedish publicly traded firms, thus making dividends the only way for firms to distribute cash to investors prior to the sample period, the reform was at least not coldly received. The governance variables show that $56 \%$ of the firms in the sample had shares with differential voting rights, and that $59 \%$ of the firms had a shareholder controlling $25 \%$ of the votes or more. Cross-listing, in contrast, is much less common: $5 \%$ of the firms in the sample were cross-listed on LSE, NASDAQ and/or NYSE.

As indicated by the VIF values accounted for in Table 2, the inclusion of the variable Log total assets in multivariate analysis creates hazards of multicollinearity. We have, however, performed all multivariate tests with this variable excluded to determine whether this is a problem. The results remained the same with this variable excluded, which indicates that it is not. 
The sample contains 164 observations of stock repurchases, which means that in an average year, around $13 \%$ of our sampled firms repurchased stock. This is slightly less than US firms; in Dittmar's (2000) sample of listed non-financial US firms, for example, 16\% of firms repurchased shares in 1995 and $20 \%$ of firms repurchased stock in 1996. The tests for equality (Table 3) show that stock-repurchasing Swedish firms tend to be larger than those that are not repurchasing shares $(\mathrm{t}=-11.75 ; \mathrm{p}<.01)$. Surprisingly, they also appear to be significantly higher leveraged $(\mathrm{t}=-2.68 ; \mathrm{p}<.01)$, have less current assets relative to total assets $(\mathrm{t}=5.11 ; \mathrm{p}<.01)$, and pay larger dividends $(\mathrm{t}=-8.03 ; \mathrm{p}<.01)$. The Wilcoxon/Mann-Whitney test, but not the t-test, also indicates that repurchasing firms have significantly higher earnings-toprice ratio $(\mathrm{z}=-12.39 ; \mathrm{p}<.01)$ and lower market-to-book ratio $(\mathrm{z}=-3.65 ; \mathrm{p}<.01)$. Repurchasing firms are also more often the subjects of take-over rumours $(\mathrm{t}=-4.7 ; \mathrm{p}<.01)$. Thus far, the data appear to be outright contradictory to the leverage hypothesis, the excess cash hypothesis, and the substitution hypothesis, while being ambiguous regarding the signalling hypothesis and supportive of the control hypothesis. Yet the important qualification that the tests for equality do not take the volume of stock repurchases into account should be stressed. The tests for equality also show that repurchasing firms tend to be cross-listed more often than nonrepurchasing firms $(\mathrm{t}=-2.62 ; \mathrm{p}<.01)$, thus suggesting that they are more exposed to pressures stemming from US and UK investors.

Table 4 reports results from OLS regressions ${ }^{3}$ with Stock repurchases as a dependent variable, hence taking into account the variability in the volume of stock repurchases the tests for equality fail to acknowledge. Information technology and 2002 are consistently used as reference categories in the estimated models. Since the sample to a large extent consists of data from the same firms over consecutive years, there is a risk of serial correlation. We control for year to preserve the independence of the observations, but also 
report Durbin-Watson statistics, all of which suggest that serial correlation is not at hand in the estimated models.

\section{Insert Table 4 here}

Models 1-2 are estimates based on the full sample. Entering the experimental variables (Model 2) greatly increases the explanatory power compared to Model 1 consisting only of control variables (Adj- $\mathrm{R}^{2}=.083$ and .223 respectively). The regression analysis indicates that stock repurchases are positively related to dividends $(\mathrm{t}=12.93 ; \mathrm{p}<.01)$. This contradicts the substitution hypothesis, suggesting instead that stock repurchases are made on top of dividends; firms that pay large dividends are more likely to repurchase large volumes of stock. Beyond that, all hypotheses based on agency theory fail this test, suggesting that patterns of stock repurchases among Swedish firms differ substantially from that among US firms.

Two governance variables are significant at the $1 \%$ level, indicating that corporate governance indeed affects stock-repurchasing behaviour. Our results suggest that firms with a shareholder in control of more than $25 \%$ of the votes tend to repurchase less stock $(\mathrm{t}=-3.72 ; \mathrm{p}<.01)$. Being cross-listed on LSE, NASDAQ and/or NYSE is positively related to stock repurchases $(\mathrm{t}=3.36 ; \mathrm{p}<.01)$. We thus find evidence to support the governance hypothesis, that firms with more traditional Swedish governance arrangements repurchase less stock. The presence of dual-class shares does, however, not predict stock repurchases in our sample, so the support is not unambiguous. Ownership concentration and heightened exposure to pressures of US or UK investors seem, however, to be of significance for Swedish firms' stock repurchasing behaviour. 
The presence of a shareholder in control of more than $25 \%$ of the votes appears to be of major importance for stock repurchases among Swedish firms. We therefore estimated two additional models: one based on the subset of firms with a large owner (Model 3) and one based on the subset of firms without a large owner (Model 4). A number of industries were only represented in one subset and the respective dummy variables were thus excluded from the estimation based on the subset in which they were not represented.

The significant positive relationship between dividends and stock repurchases $(\mathrm{t}=3.18 ; \mathrm{p}<.01 ;$ and $\mathrm{t}=12.93 ; \mathrm{p}<.01$, for Model 3 and 4 , respectively), and cross listing and stock repurchases $(\mathrm{t}=-2.64 ; \mathrm{p}<.01$; and $\mathrm{t}=2.56 ; \mathrm{p}<.05$, for Model 3 and 4 , respectively) is consistent across specifications. However, there is a significant negative relationship between leverage and stock repurchases for the subset of firms without a large owner $(\mathrm{t}=-3.46 ; \mathrm{p}<.01)$, suggesting that the leverage hypothesis can predict the behaviour of this group. Interestingly, the $\mathrm{R}^{2}$ differs substantially between the two models. The estimated model based on the subset of firms with a large owner have an Adjusted $\mathrm{R}^{2}$ of only 0.075 , whereas the model based on the subset of firms without a large owner have an Adjusted $R^{2}$ of 0.367 . This suggests that the model is a substantially better fit for firms with an ownership structure more similar to US firms, which indicates that the independent variables, largely selected based on agency theoretical explanations of stock repurchases, does a far better job at predicting stock repurchases among firms with corporate governance arrangements more similar to US firms than those with more traditional Swedish arrangements, supporting the governance hypothesis.

Overall, the only hypothesis derived from agency theory to which our results are partly supportive is the leverage hypothesis, but it only appears to predict stock repurchases among the subset of firms that do not have a large controlling shareholder. Another caveat is that the bivariate tests show that the group of stock-repurchasing firms on average is more 
highly leveraged than the non-repurchasing group, but this effect thus disappears when volume of stock repurchases are taken into account. Variables derived from the other leading hypotheses fail to predict stock repurchases, or are related to stock repurchases in the opposite direction than expected. The results differ somewhat from Bohman's (2006) study of stock repurchases in Sweden that indicates that a high return on assets and a low market-to-book may increase the probability for a firm to engage in a stock repurchase program, whereas leverage appears to be indifferent. These differences are likely attributable to the fact that Bohman studies the probability to engage in a stock repurchase program, whereas this study uses the volume of stock repurchases as dependent variable.

Some of the governance variables, in contrast, are interestingly enough significantly related to stock repurchases, indicating that stock repurchasing behaviour is affected by corporate governance arrangements. More specifically, firms with concentrated ownership seem to behave differently from those with less concentrated ownership in the sense that they repurchase less stock. Firms with less concentrated ownership seem also to behave more similarly to what has been observed among US firms. Those firms that are more exposed to the pressures of US or UK stock markets, seem also to behave differently from other firms in the sense that they repurchase more stock; this supports the governance hypothesis.

\section{DISCUSSION AND CONCLUSIONS}

Table 5 summarises our empirical results on stock repurchases among Swedish firms with regards to the five leading hypotheses on share repurchases, which are compared with earlier US research, and the governance hypothesis. We find evidence to support the governance hypothesis, that firms with more traditional Swedish corporate governance arrangements are less prone to stock repurchases. We also find evidence that partially supports the leverage hypothesis, that firms with repurchase stock alter their leverage closer to 
an optimal level - although only firms with relatively dispersed ownership do this. However, we find little evidence to support the other hypotheses based on an agency theory view of the firm, (i.e. that share repurchases are used as a mean to distribute excess cash, signal undervaluation, or fend off takeover attempts). Neither are repurchases a substitute for dividends. In fact, dividends are positively related to stock repurchases in our sample, indicating that they are made in addition to cash dividends, rather than substituting for them.

Insert Table 5 here

Overall, the results support the view that variation in corporate governance arrangements impacts stock repurchasing behaviour. We find direct evidence to suggest that firm-level governance affects stock repurchases. The pattern of stock repurchases among Swedish firms also appears to differ substantially from that of US firms. Although this is not conclusive evidence that differences in corporate governance institutions drive these differences, our results on how firm-level corporate governance arrangements affect the volume of stock repurchases in such a way that firms whose corporate governance arrangements are more similar to those of US firms (relatively less ownership concentration) and with heightened exposure to US or UK stock markets (through cross listing) repurchase more stock, support this interpretation. This is in line with Liljeblom and Pasternack (2006), who show that foreign ownership increases stock repurchases among Finnish firms, and with Ginglinger and l'Her (2006), who show that stock-price reactions to share buybacks by French firms are more positive if foreign ownership is high and there is no dominating controlling shareholder. Another finding that is consistent with the view that national corporate governance institutions partially drive these changes is that the model, consisting mostly of variables linked to hypotheses that had received previous support by US data, fits 
firms with more dispersed ownership a lot better (in terms of $\mathrm{R}^{2}$ ) than firms with a dominant controlling owner, which are common in the Swedish (Agnblad et al., 2001), but not in the US (Weimer \& Pape, 1999) context.

Hence, our results are consistent with the institutional literature arguing that agency theory suffers from US-centricity and fails to account for the effects of important institutional differences (Aguilera \& Jackson, 2003; Fligstein \& Freeland, 1995; Gospel \& Pendleton, 2005; Lubatkin et al., 2005; O'Sullivan, 2002); differences which seem to matter also for stock repurchases. The study contributes to this literature by identifying institutional factors that may be important drivers of cross-national differences in stock repurchases: controlling shareholder salience and exposure to Anglo-Saxon capital markets. Controlling shareholders are likely to have interests regarding stock repurchases that differ from autonomous managers. While approximately a third of the stock traded on SSE is owned by foreigners and Swedish firms generally have highly international sales, the existence of dominant controlling owners is also likely to shield many firms from pressures stemming from foreign investors that often seem to have a preference for stock repurchases (Ginglinger \& l'Her, 2006; Liljeblom \& Pasternack, 2006). Cross listing may, however, indicate heightened exposure to such pressures that firms, whether they have a dominant controlling owner or not, cannot resist.

What our study largely fails to do, however, is to provide a convincing explanation as to why Swedish firms repurchase stock in general. It is obvious that the leading hypotheses on stock repurchases have limited explanatory power in the Swedish context. Even though the leading hypotheses have better explanatory power for Swedish firms with relatively dispersed ownership (in terms of $\mathrm{R}^{2}$ ), they still do not have strong explanatory power even for those firms; only the leverage hypothesis seems to significantly explain stock repurchases among this subset of firms. What does seem clear, however, is that any 
explanation of stock repurchases among Swedish firms should consider that stock repurchases are likely to largely reflect the interests of controlling shareholders, rather than those of an autonomous management sensitive to capital-market pressures.

Our findings have clear implications for the literature on stock repurchases. The leading hypotheses seem to accurately predict stock repurchases only in certain (AngloAmerican) institutional and governance settings that, from a global perspective, are special cases. We also show that firm-level corporate governance can have a significant influence on incentives for stock repurchases. This highlights the need to integrate the impact of corporate governance in theorising on stock repurchases and our study contributes by indicating some factors that may influence the decision to repurchase stock.

The findings also have implications for policy makers. Specifically, the finding that differences in national and firm-specific corporate governance institutions seem to affect stock repurchases has implications for reform work. This finding essentially suggests that attempts to harmonise legislation on stock repurchases around the world (as has been done in the EU) is likely to yield stock-repurchasing behaviour that differ between countries in ways that reflect these countries' unique institutional settings. While this study certainly cannot fully substantiate such a claim, it does suggest that de jure harmonisation will not automatically lead to de facto harmonisation when it comes to stock repurchases. Policy makers need to consider the impact of their respective institutional context on the incentives to repurchase stock in order to more accurately assess the effects of reforms in this area.

The study has a number of limitations. Since we only have data from Sweden, we were unable to make direct comparisons between stock repurchases among Swedish firms and among firms in other countries. The results of this study suggests that such direct comparisons may be a promising avenue for future research, which by such comparisons should be able to, with more precision, identify those differences in national institutional 
arrangements that affect stock repurchases. One such difference between Swedish and US firms that potentially could be an important driver behind our results, is the differences in CEO compensation between the two countries (cf. Oxelheim et al., 2008; Murphy, 1999). Another potentially important factor that has not been regarded in this study is cross-national variation in board composition. Swedish firms have, for example, labour representatives on the board, who may be more interested in reinvesting excess cash than distributing them to shareholders by stock repurchases.

Another interesting avenue for future research is to develop and test hypotheses on stock repurchases in corporate governance systems characterised by concentrated ownership. One potential reason for why controlling shareholders may want to repurchase stock is to consolidate their ownership stake (cf. Ginglinger \& l'Her, 2006). By letting the firm repurchase stock and not selling privately held stock, the relative stake of the controlling owner increases. Controlling shareholders are often argued to derive private benefits from being in control (Dyck \& Zingales, 2004; Nenova, 2003; Rydqvist, 1996), so such companyfinanced consolidation of the ownership stake should be especially valuable to controlling shareholders that plausibly could face a control contest. In our sample, the absence of an owner holding more than $25 \%$ of the votes increases the volume of repurchased stock. At the same time, over $90 \%$ of all firms in the sample have a block holder controlling over $10 \%$ of the votes. Hence, most firms that repurchase stock are likely to have a controlling shareholder that could conceivably lose control over the firm. Also consistent with this conjecture is the fact that our sample contains only 11 observations of repurchases of shares with higher voting power, typically held by controlling owners, even though $60 \%$ of the repurchasing firms had dual-class shares in operation. Though these observations are in line, we do not have the data to directly capture whether this motivation drives stock repurchases in Sweden, but future research might wish to examine this hypothesis more closely. 
We thus conclude that differences in corporate governance seem to impact stock repurchases. More specifically, we conclude that controlling shareholder salience seems to be negatively related to stock repurchases and exposure to Anglo-Saxon capital markets appears to be positively related to stock repurchases. As Swedish firms typically have a much higher ownership concentration than US firms, hypotheses developed to explain stock repurchases among US firm fail to predict the behaviour of Swedish firms. Among five hypotheses, all of which are well-supported when tested with US data, only the leverage hypothesis partially predicts stock repurchasing behaviour among Swedish firms, although only among those firms that do not have a dominant controlling owner ( $>25 \%$ of votes). The excess cash hypothesis, the signalling hypothesis, the substitution hypothesis and the control hypothesis seem not to describe the stock-repurchasing behaviour among Swedish firms.

\section{NOTES}

${ }^{1}$ It could be argued that in Sweden, well-known for its high tax environment, tax considerations and repurchases should be related. Although we do not focus specifically on tax-related explanations in this study, this warrants a few comments. Capital gains are taxed at an equal rate as dividends (30\%) for physical persons, which is similar to the situation in the United States (cf. Dittmar, 2000). It could be argued that stock repurchases are beneficial for physical persons on the grounds that they are able to choose whether to realise capital gains or not, which is not possible with a dividend. However, many of the business groups use closedend investment funds in pyramid-holding structures, and for these, dividends are, if they consist of dividends from portfolio companies passed on, tax-deductible. Controlling shareholder families also often exert control by foundations (due, among other things, to past inheritance-tax laws), which are taxed in other ways. Moreover, a third of the ownership on SSE is foreign, which faces the tax situations in their home contexts. Swedish institutions are taxed in yet other ways. Altogether, it is difficult to say whether shareholders as a group would prefer stock repurchases to dividends, even if only focusing on controlling shareholders. To the extent that taxes affect preferences, we capture some of that when we test the substitution hypothesis, and whether the presence of controlling shareholders or cross listing (implying more foreign ownership) affect stock repurchases.

${ }^{2} \mathrm{We}$ also collected data on whether firms had an owner in control of more than $10 \%$ of the votes. However, since over $91 \%$ of the firms in the sample did, the variable was not very useful for analysis due to limited variation.

${ }^{3}$ The TOBIT model is another commonly used estimation technique for predicting stock repurchases (e.g., Dittmar, 2000; Sanders \& Carpenter, 2003), as it is often argued that this dependent variable is censored at zero, i.e., that information on its value is not available for some observations (cf. Gujarati, 1995). However, information on the amount of stock 
repurchases is available for all observations, those displaying zero stock repurchases have not repurchased any stock. Thus the variable is not censored, even though it is highly skewed, which is why we choose not to use the TOBIT model for our estimations. 


\section{REFERENCES}

Agnblad, J., Berglöf, E. Högfeldt, P., \& Svencar, H. 2001. Ownership and control in Sweden: strong owners, weak minorities and social control. In F. Barca \& M. Beht (eds.), The control of corporate Europe: 228-258. Oxford: Oxford University Press.

Aguilera, R.V. \& Jackson, G. 2003. The cross-national diversity of corporate governance: dimensions and determinants. Academy of Management Review, 28(3): 447-465.

Alchian, A. \& Demsetz, H. 1972. Production, information costs, and economic organization. American Economic Review, 62: 777-786.

Asquith, P. \& Mullins Jr, D. 1986. Signalling with dividends, stock repurchases, and equity issues. Financial Management, Autumn: 27-44.

Bagwell, L.S. 1991. Share repurchase and takeover deterrence. RAND Journal of Economics, 22(1): 72-88.

Bebchuk, L.A. \& Roe, M.J. 1999. A theory of path dependence in corporate ownership and governance. Stanford Law Review, 52: 127-170.

Billett, M.T. \& Xue, H. 2007. The takeover deterrent effect of open market share repurchases. Journal of Finance, 62(4): 1827-1850.

Bohman, L. 2006. Economic action and interfirm relations: diffusion of stock repurchases on the Stockholm Stock Exchange 2000-2003. European Sociological Review, 22(4): 383-396.

Chan, K., Ikenberry, D., \& Lee, I. 2004. Economic sources of gain in stock repurchases. Journal of Financial and Quantitative Analysis, 39(3): 461-479. 
Chang, S., \& Sullivan, M.J. 2007. The disparate nature of targeted repurchases: evidence from long-run performance. Journal of Business, Finance \& Accounting, 34(1-2): 65-77.

Collin, S-O. 1998. Why are these islands of conscious power found in the ocean of ownership? Institutional and governance hypotheses explaining the existence of business groups in Sweden. Journal of Management Studies, 35(6): 719-746.

Denis, D.J. 1990. Defensive changes in corporate payout policy: share repurchases and special dividends. Journal of Finance, 45(5): 1433-1456.

Dharwadkar, R., George, G., \& Brandes, P. 2000. Privatization in emerging economies: An agency theory perspective. Academy of Management Review, 25(3): 650-669.

Dittmar, A.K. 2000. Why do firms repurchase stock?. Journal of Business, 73(3): 331-355.

Dyck, A. \& Zingales, L. 2004. Private benefits of control: an international comparison. Journal of Finance, 59(2): 537-600.

Dzialo, J., Jonnergård, K., Kärreman, M., Svensson, C., \& Urbanek, P. 1998. Corporate boards' line of reasoning - comparison between corporate governance in Poland and Sweden, In M.A. Hitt, J.E.R. Costa, \& R.D. Nixon (eds.), Managing Strategically in an Interconnected World: 281-300. Chichester: John Wiley and Sons.

Eisenhardt, K.M. 1989. Agency theory: An assessment and review. Academy of Management Review, 14(1): 57-75.

Fama, E.F. \& Jensen, M.C. 1983. Separation of ownership and control. Journal of Law and Economics, 26: 301-325.

Fama, E.F. 1970. Efficient capital markets: A review of theory and empirical work. Journal of Finance, 25(2): 383-417. 
Fama, E.F. 1980. Agency problems and theory of the firm. Journal of Political Economy, 88(2): 288-307.

Fenn, G.W \& Liang, N. 2001. Corporate payout policy and managerial stock incentives. Journal of Financial Economics, 60: 45-72.

Fligstein, N. \& Freeland, R. 1995. Theoretical and comparative perspectives on corporate organization. Annual Review of Sociology, 21: 21-43.

Gedajlovic, E.R. \& Shapiro, D.M. 1998. Management and ownership effects: Evidence from five countries. Strategic Management Journal, 19: 533-553.

Gilson, R. J. 2006. Controlling shareholders and corporate governance: Complicating the comparative taxonomy. Harvard Law Review, 119(6): 1642-1680.

Ginglinger, E. \& l'Her, J-F. 2006. Ownership structure and open market stock repurchases in France. European Journal of Finance, 12(1): 77-94.

Glete, J. 1994. Nätverk i näringslivet [Networks in the business society]. Stockholm: SNS Förlag.

Gonzáles, V.M. \& Gonzáles, F. 2004. Stock repurchases with legal restrictions. Evidence from Spain. European Journal of Finance, 10(6): 526-542.

Gospel, H. \& Pendelton, A. (Eds.). 2005. Corporate governance and labour management: an international comparison. Oxford: Oxford University Press.

Grullon, G. \& Michaely, R. 2002. Dividends, share repurchases, and the substitution hypothesis. Journal of Finance, 57(4): 1649-1684. 
Guay, W. \& Harford, J. 2000. The cash-flow permanence and information content of dividend increases versus repurchases. Journal of Financial Economics, 57: 385-415.

Gujarati, D.N. 1995. Basic econometrics $3^{\text {rd }}$ edition. Boston: McGraw-Hill.

Gwilym, A.P, Morgan, O.G., \& Thomas, S. 2000. Dividend stability, dividend yield and stock returns: UK evidence. Journal of Business Finance \& Accounting, 27(3\&4): 261281.

Harris, M \& Raviv, A. 1991. The theory of capital structure. Journal of finance, 46(1): 297355.

Högfeldt, P. 2005. The history and politics of corporate ownership in Sweden. In R.K. Morck (Ed.), A history of corporate governance around the world: 517-579. Chicago: NBER.

Ikenberry, D., Lakonishok, J., \& Vermaelen, T. 1995. Market underreaction to open market share repurchases. Journal of Financial Economics, 39: 282-308.

Jagannathan, M, Stephens, C.P., \& Weisbach, M.S. 2000. Financial flexibility and the choice between dividends and stock repurchases. Journal of Financial Economics, 57: $355-384$.

Jansson, A. 2007. Collective Action Among Shareholder Activists. Växjö: Växjö University Press.

Jensen, M.C. \& Meckling, W.H. 1976. Theory of the firm: Managerial behaviour, agency costs, and capital structure. Journal of Financial Economics, 3: 305-360. 
Jensen, M.C. 1986. Agency costs of free cash flow, corporate finance, and takeovers. American Economic Review, 76(2): 323-329.

Jiraporn, P. 2006. Share repurchases, shareholder rights, and corporate governance provisions. North American Journal of Economics and Finance, 17(1): 35-48.

Jonnergård, K. \& Kärreman, M. 2004. Board activities and the denationalization of ownership - the case of Sweden. Journal of Management and Governance, 8(3): 229-254.

Jonnergård, K. \& Larsson, U. 2007. Developing codes of conduct: regulatory conversations as means for detecting institutional change. Law \& Policy, 29(4): 460-492.

Jonnergård, K. \& Larsson, U. 2010. Putting convergence on the agenda: Discourses and material condition when implementing the Swedish corporate code of conduct. In J. Jemielniak \& P. Miklaszewicz (eds), Interpretation of law in the global world: From particularism to a universal approach. Berlin: Springer.

Jun, S., Jung, M., \& Walkling, L.A. 2009. Share repurchases, executive options and wealth changes to stockholders and bondholders. Journal of Corporate Finance, 15(2): 212-229.

Kärreman, M. 1999. Styrelseledarmöters mandat - ansats till en teori om styrelsearbete $i$ börsnoterade företag [The director's mandate - a theory on the work of the board in public-listed companies]. Lund: Lund Business Press.

La Porta, R., Lopez-De-Silanes, F., \& Shleifer, A. 1999. Corporate ownership around the world. Journal of Finance, 54(2): 471-517.

Lakonishok, J. \& Vermaelen, T. 1990. Anomalous price behavior around repurchase tender offers. Journal of Finance, 45(2): 455-477. 
Lazonick, W. 2007. The US stock market and the governance of innovative enterprise.

Industrial \& Corporate Change, 16(6): 983-1036.

Liljeblom, E. \& Pasternack, D. 2006. Share repurchases, dividends and executive options: The effect of dividend protection. European Financial Management, 12(1): 7-28.

Louis, H. \& White, H. 2007. Do managers intentionally use repurchase tender offers to signal private information? Evidence from firm financial reporting behavior. Journal of Financial Economics, 85(1): 205-233.

Lubatkin, M.H., Lane, P.J., Collin, S-O., \& Very, P. 2005. Origins of corporate governance in the USA, Sweden and France. Organization Studies, 26(6): 867-889.

Murphy, K. 1999. Executive compensation. In O. Ashenfelter \& D. Card (Eds.), Handbook of Labor Economics, vol 3. Amsterdam: North-Holland.

Nenova, T. 2003. The value of corporate voting rights and control: a cross-country analysis. Journal of Financial Economics, 68(3): 325-351.

Netter, J.M. \& Michell, M.L. 1989. Stock repurchase announcements and insider transactions after the October 1987 stock market crash. Financial Management, Autumn: 84-96.

O'Sullivan, M. 2002. The political economy of comparative corporate governance. Review of International Political Economy, 10(1): 23-73.

Ofer, A.R. \& Thakor, A.V. 1987. A theory of stock price responses to alternative corporate cash disbursement methods: Stock repurchases and dividends. Journal of Finance, 42(2): 365-394. 
Oxelheim, L., Wihlborg, C., \& Zhang, J. 2008. Executive compensation and macroeconomic fluctuations. In L. Oxelheim \& C. Wihlborg (Eds.), Markets and Compensation for executives in Europe. Amsterdam: Emerald Group Publishing.

Rydqvist, K. 1996. Takeover bids and the relative prices of shares that differ in their voting rights. Journal of Banking \& Finance, 20: 1407-1425.

Sanders, G. \& Carpenter, M.A. 2003. Strategic satisficing? A behavioural-agency theory perspective on stock repurchases program announcements. Academy of Management Journal, 46(2): 160-178.

Sinani, E., Stafsudd, A., Thomsen, S., Edling, C., \& Randøy, T. 2008. Corporate governance in Scandinavia: Comparing networks and formal institutions. European Management Review, 5 (1): 27-40.

Skinner, D.J. 2008. The evolving relation between earnings, dividends and stock repurchases. Journal of Financial Economics, 87(3): 582-609.

Stafsudd, A. 2009. Corporate networks as informal governance mechanisms: A small worlds approach to Sweden. Corporate Governance: An International Review, 17(1): 6276.

Statistics Sweden. http://www.scb.se/. Accessed 2009-12-16.

Stephens, C.P \& Weisbach, M.S. 1998. Actual share reacquisitions in open market repurchase programs. Journal of Finance, 53(1): 313-333.

Strickland, D., Wiles, K.W., \& Zenner, M. 1996. A requiem for the USA: Is small shareholder monitoring effective?. Journal of Financial Economics, 40: 319-338. 
Stulz, R.M. 1990. Managerial discretion and optimal financing policies. Journal of Financial Economics, 26: 3-27.

Turnbull, S. 1997. Corporate governance: its scope, concerns and theories. Corporate Governance: An International Review, 5(4): 180-205.

Vermaelen, T. 1981. Common stock repurchases and market signalling: An empirical study. Journal of Financial Economics, 9: 139-183.

Vermaelen, T. 1984. Repurchase tender offers, signalling, and managerial incentives. Journal of Financial and Quantitative Analysis, 19: 163-181.

Walsh, J.P. \& Seward, J.K. 1990. On the efficiency of internal and external corporate control mechanisms. Academy of Management Review, 15(3): 421-458.

Wansley, J.W., Lane, W.R., \& Sarkar, S. 1989. Managements' view on share repurchase and tender offer premiums. Financial Management, Autumn: 97-110.

Weimer, J. \& Pape, J.C. 1999. A taxonomy of systems of corporate governance. Corporate Governance: An International Review, 7(2): 154-166.

Zajac, E.J. \& Westphal, J.D. 2004. The social construction of market value: Institutionalization and learning perspectives on stock market reactions. American Sociological Review, 69(3): 433-457. 
TABLE 1

Independent Variables

The leverage hypothesis

Leverage Debt/Equity Negative

The excess cash hypothesis

Current assets-to-total assets

Cash and equivalents / Total assets

Positive

Cash flow-to- total assets

Cash flow / Total assets

Positive

The substitution hypothesis

Dividends

Dividends paid

Negative

The signalling hypothesis

Market-to-book

Earnings-to-price

Market value of equity + book value of debt / Book value of equity and debt

Negative

Earnings before tax / market value of equity Negative

The control hypothesis

Rumour

1 if a takeover rumour is identified in press searches

Positive

The governance hypothesis

Differential voting rights

Crosslisting

Owner $>25 \%$

1 if the firm uses dual-class shares

1 if the firm is cross-listed on NYSE, NASDAQ and/or LSE

1 if any one owner holds $>25 \%$ of votes
Negative

Positive

Negative

Expected relation to stock repurchases 
TABLE 2

Descriptive Statistics and Correlations

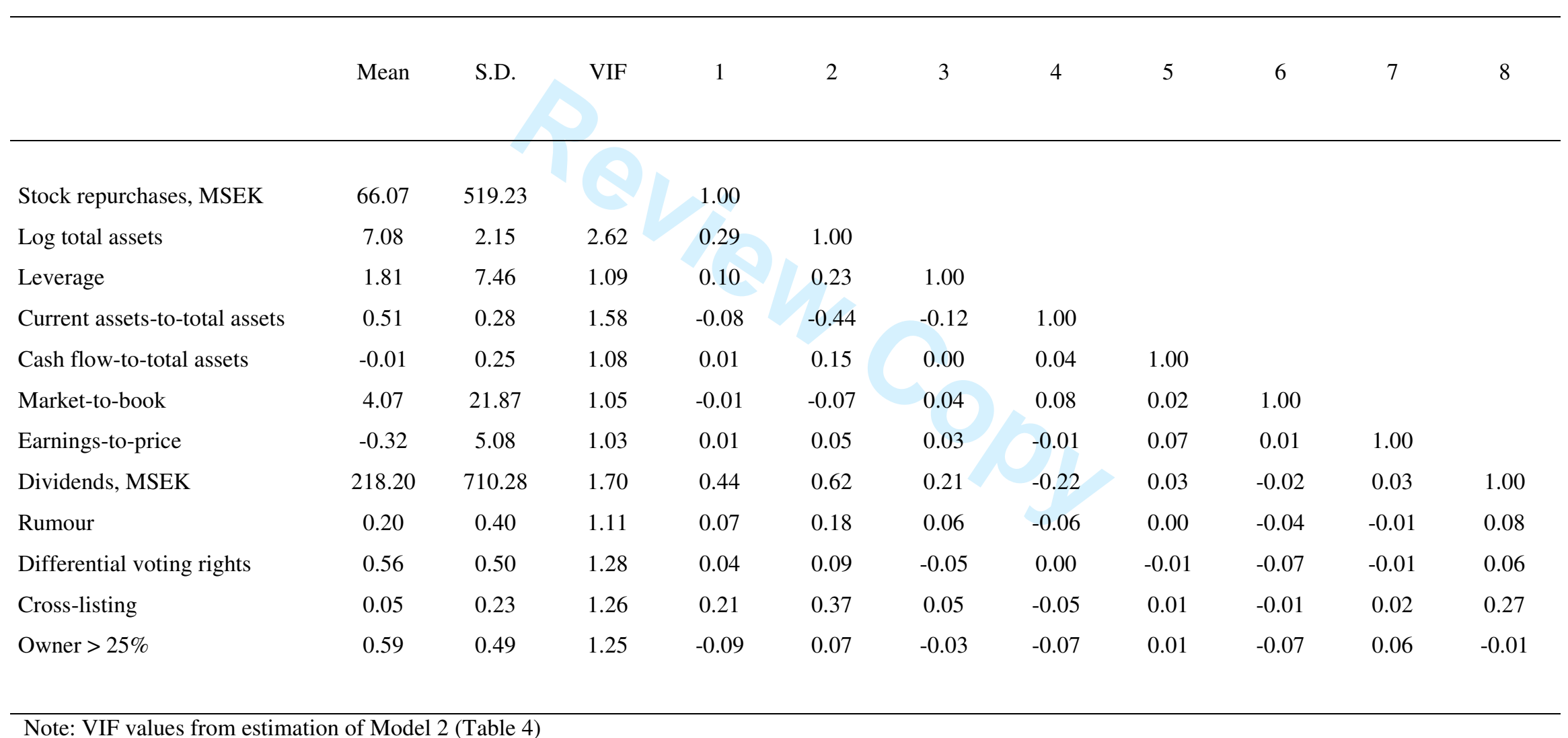




\section{Page 45 of 49}

Corporate Governance: An International Review

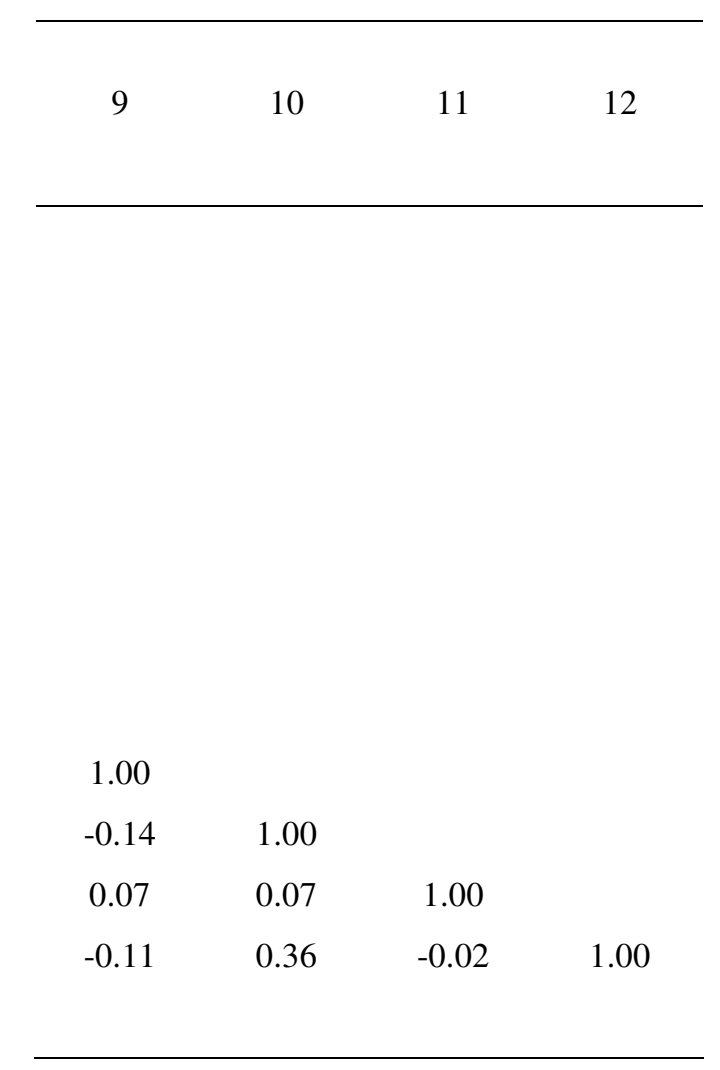


TABLE 3

Tests for Equality

\begin{tabular}{|c|c|c|c|c|}
\hline & $\begin{array}{c}\text { Non- } \\
\text { Repurchasers } \\
(\mathrm{n}=1145)\end{array}$ & $\begin{array}{l}\text { Repurchasers } \\
\quad(\mathrm{n}=164)\end{array}$ & $\mathrm{t}$ & $\mathrm{z}$ \\
\hline Log total assets & 6.83 & 8.84 & $-11.75^{* *}$ & $-11.06^{* *}$ \\
\hline Leverage & 1.60 & 3.26 & $-2.68 * *$ & $-4.09 * *$ \\
\hline Current assets-to-total assets & 0.53 & 0.41 & $5.11 * *$ & $-4.70 * *$ \\
\hline Cash flow-to-total assets & -0.02 & 0.01 & -1.33 & -0.21 \\
\hline Market-to-book & 4.37 & 1.96 & 1.32 & $-3.65 * *$ \\
\hline Earnings-to-price & -0.39 & 0.13 & -1.22 & $-12.39 * *$ \\
\hline Dividends, MSEK & 159.94 & 624.94 & $-8.03 * *$ & $-12.75^{* *}$ \\
\hline Rumor & 0.18 & 0.34 & $-4.70 * *$ & $-4.66 * *$ \\
\hline Differential voting rights & 0.55 & 0.60 & -1.14 & -1.14 \\
\hline Cross-listing & 0.05 & 0.10 & $-2.62 * *$ & $-2.62 * *$ \\
\hline Owner $>25 \%$ & 0.60 & 0.57 & 0.59 & -0.59 \\
\hline
\end{tabular}

Note: ${ }^{\dagger} \mathrm{p}<.10, * \mathrm{p}<.05,{ }^{* *} \mathrm{p}<.01$ 
TABLE 4

Results of OLS Regressions with Stock Repurchases as Dependent Variable

\begin{tabular}{|c|c|c|c|c|c|c|c|c|}
\hline & \multicolumn{2}{|c|}{$\begin{array}{l}\text { Model } 1 \\
\text { (all firms) }\end{array}$} & \multicolumn{2}{|c|}{$\begin{array}{l}\text { Model } 2 \\
\text { (all firms) }\end{array}$} & \multicolumn{2}{|c|}{$\begin{array}{c}\text { Model } 3 \\
\text { (firms with owner }>25 \%)\end{array}$} & \multicolumn{2}{|c|}{$\begin{array}{c}\text { Model } 4 \\
(\text { firms with no owner }>25 \%)\end{array}$} \\
\hline & Coefficient & Std. Error & Coefficient & Std. Error & Coefficient & Std. Error & Coefficient & Std. Error \\
\hline Log total assets & $77.17 * *$ & 7.45 & -1.07 & 9.65 & $21.20 * *$ & 5.50 & -4.35 & 20.85 \\
\hline Leverage & & & 0.45 & 1.80 & 1.10 & 0.86 & $-17.66^{*}$ & 7.30 \\
\hline Current assets-to-total assets & & & 47.63 & 58.38 & 50.16 & 36.55 & 45.90 & 110.01 \\
\hline Cash flow-to-total assets & & & -26.45 & 53.21 & -16.00 & 33.26 & -47.93 & 102.82 \\
\hline Market-to-book & & & -0.41 & 0.60 & -0.97 & 1.23 & -0.37 & 0.83 \\
\hline Earnings-to-price & & & -0.04 & 2.55 & -10.35 & 11.17 & -0.32 & 3.45 \\
\hline Dividends, MSEK & & & $0.30 * *$ & 0.02 & $0.04 * *$ & 0.01 & $0.64 * *$ & 0.05 \\
\hline Rumour & & & 37.99 & 33.69 & 1.13 & 20.40 & 84.50 & 65.44 \\
\hline Cross-listing & & & $213.01 * *$ & 63.34 & $-95.50 * *$ & 36.18 & $360.17 *$ & 140.61 \\
\hline Owner $>25 \%$ & & & $-108.52 * *$ & 29.15 & & & & \\
\hline Energy & 141.46 & 224.30 & 6.03 & 210.40 & 48.15 & 91.41 & & \\
\hline Materials & -91.28 & 60.62 & -21.62 & 58.87 & 23.70 & 32.18 & -28.69 & 135.99 \\
\hline Industrials & -41.83 & 40.05 & 36.69 & 38.81 & -15.46 & 23.05 & -33.62 & 79.62 \\
\hline Consumer discretionary & -39.17 & 50.69 & 44.20 & 48.57 & -5.01 & 26.47 & 50.37 & 114.24 \\
\hline Consumer staples & -16.96 & 104.37 & 130.15 & 98.81 & -21.69 & 51.12 & 73.15 & 260.16 \\
\hline Health care & -34.86 & 53.20 & -7.94 & 49.89 & -4.74 & 32.49 & -13.29 & 88.85 \\
\hline Financials & -74.80 & 48.24 & 31.06 & 50.52 & 25.06 & 29.75 & -101.18 & 110.31 \\
\hline Telecommunication services & $-200.20^{*}$ & 101.21 & -77.70 & 95.71 & -40.25 & 48.37 & 27.92 & 259.97 \\
\hline
\end{tabular}




\begin{tabular}{|c|c|c|c|c|c|c|c|c|}
\hline Utilities & -270.83 & 251.37 & 34.08 & 237.41 & -47.29 & 103,89 & & \\
\hline 2000 & $99.88 *$ & 44.17 & $98.38 *$ & 42.33 & $53.84 *$ & 23,68 & $206,92 *$ & 90,58 \\
\hline 2001 & 42.17 & 42.74 & 37.76 & 40.30 & 9.81 & 22,71 & 84,56 & 84,43 \\
\hline 2003 & 15.49 & 42.26 & 2.76 & 39.62 & -7.70 & 22,17 & 21,05 & 82,36 \\
\hline Adj-R2 & \multicolumn{2}{|c|}{0.083} & \multicolumn{2}{|c|}{0.223} & \multicolumn{2}{|c|}{0.075} & \multicolumn{2}{|c|}{0.367} \\
\hline Durbin-Watson & \multicolumn{2}{|c|}{2.051} & \multicolumn{2}{|c|}{1.980} & \multicolumn{2}{|c|}{2.002} & \multicolumn{2}{|c|}{2.013} \\
\hline
\end{tabular}

Note: ${ }^{\dagger} \mathrm{p}<.10, * \mathrm{p}<.05, * * \mathrm{p}<.01$ 
TABLE 5

Results Compared with Previous Research using US Data

Hypothesis

The leverage hypothesis

The excess cash hypothesis

The substitution hypothesis

The signalling hypothesis

The control hypothesis

The governance hypothesis

\section{Studies suggesting the hypothesis' explanatory \\ Results of this study} power for US firms

Ofer and Thakor (1987); Wansley et al. (1989); and Dittmar (2000)

Supportive only for firms without owner $>25 \%$

Unsupportive

Stephens and Weisbach (1998); Dittmar (2000); Jagannathan et al. (2000); Guay and Harford (2000); and Fenn and Liang (2001)

Grullon and Michaely (2002); and Skinner (2008)

Unsupportive

Vermaelen (1981); Netter and Mitchell (1989);

Unsupportive Lakonishok and Vermaelen (1990); Ikenberry et al. (1995); Louis and White (2007); Chang and Sullivan (2007); and Jun et al. (2009)

Vermaelen (1984); Denis (1990); Dittmar (2000); Unsupportive Chang and Sullivan (2007); and Billett and Xue (2007) 